\title{
"QUANDO 0 INIMIGO TE ABRAÇA COM ENTUSIASMO...": ETNOGRAFIA DE UMA TRAIÇÃO
}

Mauricio Fernando Boivin, Ana Rosato e Fernando Alberto Balbi

Quando o inimigo te abraça com entusiasmo e teus concidadãos te rejeitam com rancor, é difícil que não te perguntes se não és, na realidade, um traidor (Ursula Kroeber Le Guin, Os Despossuídos).

\section{Introdução}

Os preparativos para a comemoração estavam quase no fim, quando chegou a notícia da derrota. Haviam interditado a rua onde fica a sede do Partido e montado um tablado onde aconteceria o "baile da vitória". Cerca de trezentas pessoas já tinham chegado e dado início a um clima festivo, com bumbos e batucadas, consumindo boa parte da cerveja e do vinho, generosamente calculados. A vitória estava de tal forma garantida que o Partido sequer organizara a totalização eletrônica dos votos para sistematizar as informações eleitorais trazidas pelos fiscais. Nas palavras de um militante1: "estávamos tão seguros de que ganharíamos que nem mesmo ligamos o computador".

No entanto, às 20 horas, os resultados finais são divulgados: o Partido acabava de perder a Prefeitura por um punhado de votos. Rapidamente, a alegria transforma-se em estupor e desolação. Homens e mulheres choram, enquanto uns poucos tentam consolar os demais, argumentando que o Partido ganhara nos planos nacional, provincial e departamental. Porém, perdera-se a Prefeitura, perdera-se o povo, e o sentimento dominante não podia ser outro senão o de derrota.

Uma hora mais tarde, o candidato a prefeito derrotado vai cumprimentar o vencedor. Quando retorna à sede do Partido, fala brevemente a seus partidários, abrindo caminho para o discurso do líder do Partido. Este ressalta as virtudes do candidato, promete uma volta triunfal à Pre- 
feitura dentro de quatro anos e explica a derrota com uma simples frase: "Companheiros, todos sabemos quem são os traidores".

De fato, todos sabem, e não demoram em encontrá-los na multidão. Um homem que estava dentro da sede do Partido, lendo os resultados, é encarado por vários militantes que, aos gritos de "traidor", se atracam com ele. Um deles, segundo testemunhas, dá-Ihe um "soco no meio da cara". O homem cambaleia, recompõe-se, recua até o pátio e, sempre encarado pelas pessoas que Ihe gritam insultos, chega aos fundos do terreno e consegue fugir pulando para a casa vizinha. Alheio ao que acontece, o líder continua o seu discurso, enquanto as pessoas entoam a marcha do Partido e gritam: "Traição! Traição!".

Dentro da sede, outro homem é agredido. Tenta sair pela porta principal, mas, à medida que avança, homens e mulheres dão-lhe socos e chutes, sempre gritando "traidor!". Por fim, consegue chegar à porta. Ao perceber o que acontece, o presidente do Partido aproxima-se e se interpõe entre ele e os furiosos, pedindo calma. Protegendo-Ihe as costas, leva-o pela calçada até a casa da esquina. As pessoas seguem-nos aos gritos e uma ou outra logra atingi-lo. Finalmente, o homem refugia-se na casa, defronte da qual se acotovelam as pessoas, sempre gritando: "Traidor! Traidor!". Depois de um tempo, a polícia chega e o retira, protegido em uma ambulância. A pós a fuga, os dirigentes conseguem tranqüilizar as pessoas e dispersá-las calmamente.

Quem são esses traidores e em que consistiu sua traição? Trata-se do chefe de uma das correntes internas do Partido e de seu secretário de imprensa. A traição: segundo os acusadores, eles entregaram "seus votos" - os votos de seus seguidores - ao candidato do partido vencedor. M as, fizeram isto realmente? E se o fizeram, quais foram as razões? E, sobretudo, por que foram acusados de traição, isto é, o que significa traição e por que foi este o qualificativo que receberam as ações imputadas a eles? Para responder a estas perguntas é preciso, antes de tudo, conhecer os antecedentes imediatos do incidente em questão.

\section{Os traidores e a traição}

Os acontecimentos que narramos ocorreram em uma pequena cidade do litoral argentino 2 . Com cerca de 20.000 habitantes, trata-se de um centro comercial e de serviços voltado para atender aos estabelecimentos agropecuários da região. Tradicional reduto da União Cívica Radical ${ }^{3}$, essa cidade assistiu ao triunfo do Partido J usticialista4 ${ }^{4}$ nas eleições de 1987.0 
candidato vencedor, J ulio Cesar Solari, era membro de um pequeno grupo que conseguira, em 1983, afastar o antigo caudilho que comandava o Partido desde a década anterior. Solari fora eleito deputado provincial em 1983, único êxito peronista daquele ano. Em 1987, entretanto, e mais tarde em 1991, o peronismo obteve êxito total: prefeito, deputado provincial, senador provincial, maioria na Câmara de Vereadores.

Durante esse período, Solari tornou-se líder do Partido no plano local. Foi deputado, prefeito, outra vez deputado e, finalmente, candidato a senador nas eleições de 14 de maio de 1995, das quais saiu vencedor. Independente das diferentes posições que ocupou, sempre manteve a capacidade de distribuir entre seus colaboradores mais próximos cargos públicos departamentais, municipais e provinciais, assim como cargos partidários. Entretanto, o grupo que conquistara a vitória inicial se desarticulara diante das novas pressões que emanavam da luta pelo poder entre seus integrantes, particularmente entre Solari e o deputado provincial eleito em 1987. Enquanto esta divisão interna se produzia, Solari começava a rodear-se de novos seguidores, dentre os quais Ramón, "Moncho" Córdoba, o primeiro de nossos traidores.

M oncho chegou à cidade em abril de 1988 para assumir a Direção Municipal de Pesca. Nas eleições de 1987, Solari obtivera muitos votos no bairro onde reside a maioria dos pescadores da cidade, em grande medida graças ao fato de ter conseguido incorporar um pescador de prestígio à sua campanha, com o compromisso de criar uma direção de pesca no plano municipal e colocá-la em suas mãos. A promessa de ter um organismo de controle da atividade em poder de um pescador respeitado atraiu muitos votos. No entanto, alguns meses mais tarde, Solari nomeou M oncho para esse cargo, um desconhecido para os pescadores da localidade.

A relação entre eles era tanto pessoal quanto política. M oncho havia sido chofer de Solari quando este era deputado provincial, e Solari precisava naquele momento cercar-se de gente em quem pudesse confiar. Este não era, certamente, o caso do homem a quem ele recorrera para obter os votos dos pescadores. Por isso, parecia lógico nomear M oncho para a estratégica nova direção - que constituía uma instância propícia à organização social e política desses trabalhadores - , especialmente levando em conta que ele tinha sido pescador.

O verdadeiro papel de $M$ oncho, no entanto, ia muito além do controle municipal da atividade pesqueira. De fato, ele era, antes de tudo, um homem da confiança de Solari, em cujas mãos este depositou a galinha dos ovos políticos de ouro: o corralón municipal. O corralón é o órgão municipal encarregado da manutenção e limpeza da cidade, funções para 
as quais distribui horas extras, ao mesmo tempo que controla um grande contingente de pessoal contratado (isto é, temporário). Constitui, portanto, um lugar estratégico para obter e manipular recursos, cuja distribuição é peça fundamental do trabalho de um cabo eleitoral [puntero]5: tijoIos, placas de metal, colchões etc. Como encarregado do corralón e diretor de pesca, Moncho controlava um potencial de recursos que era o sonho de qualquer cabo eleitoral local.

Cabo eleitoral em plena ascensão, M oncho desempenhou uma atividade intensa que Ihe permitiu consolidar sua posição rapidamente. No corralón, ele repartiu favores; na Direção de Pesca, desenvolveu uma série de projetos - nunca concretizados - referentes a todas as atividades relacionadas com a zona portuária. Além disso, os empregados contratados da Direção de Pesca passaram a integrar o quadro de funcionários permanentes da Prefeitura. Ao cabo de um ano, não havia praticamente nenhuma atividade política da Prefeitura com a qual M oncho não estivesse envolvido. Durante os anos seguintes, até as prévias eleitorais do Partido em 1994, M oncho continuou desenvolvendo uma intensa atividade política, sempre fazendo parte do círculo de colaboradores mais próximos de Solari.

N osso segundo traidor, Esteban Carbonari, é um médico pediatra que começou a atuar na política local por volta de 1987. Nascido na cidade, Carbonari, depois de uma ausência de cinco anos, voltou como responsável local por um projeto provincial de pronto atendimento na área de saúde. Não por acaso, seu acesso ao cargo revelava seus contatos com o então ministro do Governo, Educação e J ustiça da província e que logo seria, entre 1991 e 1995, vice-governador. Recém-chegado à cidade, o Doutor começou seu trabalho político, que resultou na fundação de um grupo local ligado à corrente provincial do ministro, pela qual estreou nas prévias para deputado provincial de 1989. Sempre como pré-candidato a prefeito, o Doutor competiu nas prévias eleitorais do Partido em 1991 e 1995, sendo derrotado em ambas as ocasiões pela corrente de Solari. Durante todo esse tempo, sua condição de pediatra do único hospital público da cidade Ihe serviu como base de atuação política, como um vínculo direto com o segmento mais humilde da população. As prévias realizadas antes das el eições gerais de 1995 iriam uni-lo a M oncho.

De que maneira Moncho, homem de confiança de Solari, chegou a alinhar-se com seu rival? Talvez a melhor forma de compreender este fato seja indagando sobre as aspirações de $M$ oncho e as possibilidades que tinha de satisfazê-las através de sua relação com Solari. 
M oncho tinha se tornado um ativo cabo eleitoral da corrente interna de Solari. Depois que deixou o corralón para se dedicar integralmente à Direção de Pesca, foi obrigado a abandonar também este cargo em função do resultado das prévias disputadas entre seu chefe e o deputado provincial pelo controle local do Partido. A Direção de Pesca - devido precisamente ao trabalho de $\mathrm{M}$ oncho - havia se transformado em um espaço político importante que o deputado tratou primeiro de ocupar e, mais tarde, de destruir. Depois de uma enxurrada de acusações de corrupção promovida pel o deputado contra o grupo de Solari, este realizou uma série de mudanças em sua equipe de governo, sendo uma delas a saída de M oncho da Direção. A pesar disso, M oncho continuou ao lado de Solari até o momento em que a derrota definitiva do deputado na luta pelo controle do peronismo local lhe abriu espaço para retornar ao cargo de Diretor Municipal de Pesca.

N o entanto, a Direção não era o limite das aspirações de M oncho. Mas, o que ele poderia pretender além disso? Ele carecia de qualquer tipo de formação profissional, o que tornava pouco provável que algum dia tivesse acesso a um cargo de relevância no poder executivo provincial. Consciente disso, propunha-se a lutar por um cargo eletivo.

O cargo que, em princípio, Ihe interessava era o de senador provincial. Já em 1992, ele começara a manifestar suas aspirações e a agir nesse sentido. Porém, quando ocorreram as prévias das eleições de maio de 1995, viu frustrada sua ambição, já que Solari havia reservado a vaga de senador para si.

Por outro lado, os cargos eletivos aos quais pode aspirar um político da cidade não são muitos. Além do prefeito, existem doze vereadores (deste total é improvável que um partido consiga eleger mais de seis ou sete), um senador provincial e, com sorte, um deputado provincial — os deputados são votados considerando a província como um único distrito, e é muito difícil que um departamento coloque mais de um candidato em uma boa posição em cada lista el eitoral. Em suma, um cál culo generoso soma um total de dez cargos, o que significa que a distribuição das candidaturas é um assunto delicado. Portanto, Solari dispunha de muito poucas posições para atender a seus colaboradores e aliados.

A pós algumas indecisões, Solari decidiu oferecer a pré-candidatura a prefeito para Venancio Simoni, um jovem dirigente que fora seu secretário de governo e que, naquele momento, era funcionário do governo provincial. Por outro lado, Solari apoiou para pré-candidato a deputado provincial outro de seus aliados que era, então, o prefeito. Quanto às précandidaturas a vereador, estas foram parar em mãos de outros homens 
dos círculos de Solari e Simoni, as quais, em geral, foram reservadas para destacados cabos eleitorais de bairros. A pergunta é: por que M oncho não recebeu nada nessa partilha?

As razões para isso parecem ter sido três. Em primeiro lugar, Solari achava que $M$ oncho não estava capacitado para atingir posições mais elevadas. Considerava-o um bom cabo el eitoral e um quadro útil para serviços específicos, como participar da tropa de choque na Assembléia por ocasião da votação de uma lei polêmica. Não o via, contudo, como al guém capacitado para tarefas de maior responsabilidade, para cargos de nível mais elevado.

Em segundo lugar, ainda que $M$ oncho fosse um cabo eleitoral, não dispunha de base em nenhum bairro. Sua área de ação era a zona portuária, densa em atividades, mas quase desabitada. Isto impunha limites relativamente estreitos à quantidade de pessoas sobre cujos votos $\mathrm{M}$ oncho poderia ter influência. Mais do que isso, seu trabalho político estava dirigido a pessoas que, por viverem em outras partes da cidade, eram atingidas também por outros cabos el eitorais. Seu trabalho era, pois, pouco eficaz ou, pelo menos, poderia ser acusado disso.

Finalmente, faltava a M oncho raízes locais. Do ponto de vista da militância era um parvenue, um recém-chegado à política local. Sete anos de militância na cidade não eram suficientes: M oncho não estava inserido na rede de relações de parentesco que informava a política no âmbito do bairro. A maioria dos cabos el eitorais nasceu e cresceu, se não no bairro onde atuava, pelo menos na cidade, e possuía vínculos de parentesco entre si - e, às vezes, com seus chefes políticos. Assim, por exemplo, um cabo eleitoral que foi vereador é pai de um dos atuais vereadores e sogro de Venancio Simoni. Em outro bairro, o pescador a quem Solari prometera a Direção de Pesca e seus irmãos formam um grupo de cabos eleitorais que compete com outra família.

Tudo parecia indicar que a candidatura de M oncho não seria digerível para os companheiros 6 . Definitivamente, ele não só aspirava ao cargo eletivo errado, como estava enganado ao pretender aspirar a um cargo eletivo. Daí sua traição, o que nos leva de volta ao Doutor.

As prévias do Partido para as eleições gerais de 1995 foram realizadas no dia 5 de março. Além da chapa de Solari - cuja configuração final já foi vista - , outras duas listas competiram pelo acesso às candidaturas partidárias: uma liderada pelo Doutor e outra que apresentava como précandidato a prefeito "Tony" Nardone, um veterano político que fora vereador em 1973 e que, naquele momento, era senador provincial. M oncho não figurava em nenhuma das duas listas, mas trabalhava como por- 
ta-voz de imprensa do Doutor e afirmava que se a sua lista ganhasse, ele seria secretário do Partido no plano departamental.

De Solari ao Doutor, de senador a secretário do Partido, o caminho de Moncho fora longo e complexo. Seu rompimento com Solari pode ser rastreado até os primeiros meses de 1994, quando apoiou o nome do então presidente local do Partido para pré-candidato a prefeito. Homem de extrema confiança de Solari, o presidente do Partido havia integrado com ele o grupo que conseguira as primeiras vitórias para o J usticialismo em 1983 e 1987, e havia sido secretário de governo e de ação social durante seu mandato como prefeito. Era, para muitos, o candidato natural à Prefeitura. Para as prévias eleitorais de 1995, Solari pensou, inicialmente, em propô-lo para esse cargo. M oncho - entre outros militantes - apoiou essa indicação com entusiasmo porque, como dizia, Solari havia ordenado que a promovesse. No entanto, mais tarde, Solari mudou de idéia e propôs a pré-candidatura de Simoni, o que criou constrangimentos para M oncho. Não nos foi possível saber com certeza se é verdade que M oncho tinha atuado sob as ordens de Solari - algo bastante provável - ou se operara por conta própria. O certo é que Solari desarticulou as tentativas feitas por Moncho e por um grupo de militantes a ele chegado.

Ainda que se mostrasse muito ressentido por achar que foi usado para uma manobra política e, apesar de ter perdido novamente a Direção de Pesca (em função de novas acusações de corrupção), M oncho permaneceu ao lado de Solari até dezembro de 1994. A data de seu afastamento não é casual: nesse mês se soube que Solari não seria - como se especulava até então - pré-candidato a vice-governador pela corrente que ele apoiava no plano provincial. Isto teria implicado um aumento das possibilidades do nosso homem. Para começar, se Solari tivesse deixado livre a candidatura a senador, M oncho teria podido lutar por ela. A lém do mais, a pré-candidatura de Solari a vice-governador significava a possibilidade de outros homens que o cercavam terem acesso a cargos de importância na administração provincial, deixando vagas algumas posições municipais, às quais Moncho poderia aspirar.

M oncho procurou Tony Nardone, com quem tentou negociar uma candidatura a vereador. Nardone parecia disposto a concedê-la, mas os protestos de seus militantes impediram-no. Por mais votos que parecesse capaz de atrair, M oncho não deixava de ser um recém-chegado. Uma tentativa posterior de colocar nessa mesma candidatura uma militante de seu grupo fal hou pelas mesmas razões. N osso homem passou, então, a negociar com o Doutor, com quem finalmente teve êxito. De aspirante a senador pela corrente majoritária, passara a aspirante a secretário do Par- 
tido por uma corrente da oposição. No entanto, podia considerar-se afortunado, dado que sua relação com Solari, que antes fora um ponto a seu favor, não passava agora de um estigma e que seu trabalho prévio como militante nada significava fora da corrente de Solari.

A lista de Solari triunfou nas prévias eleitorais, ainda que por uma margem bem mais estreita do que a alcançada em prévias anteriores. Em segundo lugar, ficou a lista do Doutor, e em terceiro, bem distante, a de Nardone. Sobre um total de pouco mais de 5.500 votos, as diferenças foram de 287 para prefeito, 405 para senador e 635 para deputado.

A estreiteza dessas margens permitiu ao grupo do Doutor autoproclamar-se - nas palavras de um militante - "vencedor moral" da disputa. Se as duas listas minoritárias tivessem se unido - segundo o raciocínio tanto deles quanto dos meios de comunicação locais - teriam ganho com tranqüilidade. Para prefeito, por exemplo, a lista de Solari obteve $42,8 \%$ contra os $57,2 \%$ da oposição.

Talvez devêssemos buscar os germes da traição nessa sensação de vitória moral. De fato, assim que terminaram as prévias eleitorais, começaram os indícios de que algo fora do comum iria acontecer nas eleições gerais. Tony $\mathrm{N}$ ardone iniciou contatos com o Doutor com o intuito de somar forças para negociar com Solari sua inclusão na lista do Partido (o regimento do J usticialismo provincial não prevê mecanismo automático algum de distribuição das candidaturas entre a maioria e a primeira minoria de acordo com os resultados das prévias). Ao mesmo tempo, no entanto, delineou-se a possibilidade de o Doutor abandonar o J usticialismo: correram rumores de que - apenas quatro dias depois de sua vitória moral - ele viajara a Buenos Aires para ter um encontro com J osé Octavio "Pilo" Bordón, o líder do partido PAIS, um dos dois sócios principais da segunda força de oposição no plano nacional, a Frente Pais Solidario (Frepaso)7. No dia seguinte, os principais dirigentes do grupo do Doutor se reuniram para avaliar a estratégia a ser seguida. As opções eram: unirse à Frepaso nos planos provincial e nacional, ocupando a maior parte das candidaturas no plano local, ou formar um grupo independente, "de caráter municipal". Essa intensa atividade negociadora respondia a uma razão concreta: as eleições gerais deveriam acontecer apenas sessenta dias depois das prévias - um prazo inquietante para o grupo de Solari, onde se ouviam queixas de que o cronograma eleitoral deixava "pouco tempo para curar as feridas das prévias".

As negociações com $\mathrm{N}$ ardone prolongaram-se, assim como a atitude vacilante do nosso homem. Doze dias se passaram desde as prévias quando, em uma noite agitada, se reuniram, os dirigentes e, em seguida, toda 
a militância das duas facções. Ainda que nessas reuniões se descartasse a idéia de formar um novo grupo municipal, porque não havia tempo suficiente para fazê-lo, a idéia de ir por fora do Partido, mediante uma aliança com o PAIS, continuou predominando.

Finalmente, Nardone afastou-se do Doutor. $M$ ais tarde, este afirmaria que "com certeza, deve ter havido al gum tipo de arranjo entre Solari e Nardone", apesar de que nem o último nem nenhum de seus colaboradores se somaram à lista do Partido para as eleições. Por sua parte, dirigentes locais da Frepaso declararam publicamente que não aceitariam a incorporação do grupo do Doutor, acusando-o de oportunismo político.

Dezessete dias após as prévias, uma nova assembléia com a presença de mais de quatrocentas pessoas decidiu que o grupo levaria mais três dias para "esgotar as tentativas com a atual direção, procurando evitar uma divisão", ou, em outras palavras, negociar com Solari a conformação da lista. Havia vários dias, no entanto, que a imprensa registrava rumores de que o Doutor negociava com Solari. Dizia-se que o Doutor colocaria um dos seus na lista de vereadores, porque Solari criaria uma vaga, afastando seu cabo eleitoral no bairro dos pescadores, tradicional reduto que o Doutor Ihe havia arrebatado nas prévias.

No dia seguinte, em uma fazenda próxima à cidade, os dois dirigentes se encontraram. O vice-governador em exercício, mentor político do Doutor, interveio - diz-se que como mediador. Confirmando os rumores, o cabo eleitoral de Solari no bairro dos pescadores foi substituído na lista de candidatos a vereadores por Nilda Avente, uma militante do setor de oposição.

Pode-se dizer que, nesse momento, os indícios de que ocorreria algo pouco comum se transformavam em presságios de traição. A pesar do acordo al cançado pelos dois dirigentes, cresciam os rumores de que os militantes do Doutor estavam "tentando convencer as pessoas" a "cortarem a cédula", votando em $\mathrm{N}$ ardo Liporacce, o candidato a prefeito pelo Radicalismo8.

Assim, a um mês das eleições, os radicais organizaram um ato em um bairro da cidade, ao qual assistiram - segundo o jornal local - muitos justicial istas "de base, militantes ativos". Embora o jornal pertença a uma dirigente da UCR e expresse os interesses desse partido, pode-se confiar na veracidade da notícia uma vez que um dos oradores do ato foi Pablo Dieguez, cabo eleitoral local do grupo do Doutor. Também compareceu a presidenta do Sindicato das Donas de Casa, dirigente justicialista da facção de Tony Nardone, liderando um grupo de representantes de sua associação. 
Esse mesmo jornal, a onze dias das eleições, publicou uma suposta "carta anônima de leitores" - quase com certeza por seu editorialista -, segundo a qual, logo após as el eições gerais, seriam expulsos do J usticialismo

“[...] alguns afiliados que abertamente participaram de outros grupos políticos, insultando publicamente, através de todos os meios radiofônicos e/ou televisivos, os candidatos surgidos das prévias [...]. O mesmo fim teriam alguns afiliados que, na propaganda de rua, se converteram em críticos impiedosos da direção local do partido [...] [Se isso ocorresse, seria] um fato inédito entre os adeptos da direção partidária [...]. A razão que sutentaria essa (sic) medida drástica seria a de grave conduta (sic) partidária".

À medida que se aproximava o dia das eleições, multiplicavam-se as declarações públicas de militantes de bairro da facção do Doutor, manifestando que não iriam votar em Venancio Simoni para prefeito, alegando, em geral, desconfiança a respeito da capacidade pessoal do candidato. O J usticialismo, no entanto, parecia firme: a "caravana da vitória", realizada a nove dias das eleições, reuniu cerca de 120 veículos que acompanharam os candidatos em seu percurso pelos bairros da cidade e, a despeito da chuva fina persistente, uma multidão saudou sua passagem.

Enquanto isso, o Partido montava o esquema habitual para o dia da votação. Alguns militantes eram designados fiscais e outros eram incumbidos de "levar as pessoas para votar", isto é, de levar aos lugares de votação idosos, inválidos e todos os simpatizantes que morassem longe. Para isso, alguns veículos de transporte público foram especialmente alugados, e militantes, filiados e simpatizantes foram convocados a emprestar seus carros. Por fim, organizou-se a distribuição de alimentos para os fiscais e a preparação e repartição das cédulas.

Esse esquema, montado vários dias antes, não poderia prever a chuva torrencial que desabou durante a noite anterior à votação. Um fato perfeitamente natural adquiriu para os militantes uma forte significação. Em primeiro lugar, o temporal - que veio precedido de uma prolongada seca - obrigou-os a providenciar, em cima da hora, veículos capazes de "tirar" as pessoas que vivem no campo ou nas ruas de terra da cidade (isto é, caminhonetes, tratores e carroças). A pesar de o problema ter sido contornado a tempo pelos organizadores, alguns militantes - talvez transferindo à natureza o temor originado pela incerteza política dos últimos meses - consideraram-no como um sinal antecipado da derrota pois, 
diziam com fatalismo, os radicais "têm mais caminhonetes". Como se isso fosse pouco, quando o presidente do Partido visitava uma área inundada da cidade para colaborar na assistência às famílias desabrigadas por causa das chuvas, um afiliado Ihe contou que nesse mesmo dia o presidente da comissão de bairro, um companheiro, tinha se aproximado sugerindoIhe que cortasse a cédula em detrimento do candidato a prefeito.

Com presságios tão funestos, chegou final mente o dia das eleições. Enquanto ocorria a votação e se organizava o então chamado baile da vitória, surgiu o último e mais terrível de todos os presságios: correu a notícia de que foram encontradas cédulas cortadas, sem a seção correspondente a prefeito, nos carros em que os militantes da facção do Doutor levavam sua gente para votar. Preocupados, alguns dos homens de Solari se mostravam surpresos com o fervor militante dos partidários do Doutor, que participavam muito ativamente do esquema de atividades eleitorais.

Perto das 18 horas, hora do fechamento da atividade eleitoral, a tensão aumentou. Os jornais, rádios e televisões locais se instalaram na sede do Partido, concentrando seus modestos recursos ali onde esperavam encontrar os vencedores. Os resultados locais começaram a chegar mesa por mesa, seguindo a tendência geral para os cargos nacionais - revelada pelas pesquisas de boca-de-urna realizadas pelos canais de televisão da Capital Federal que, segundos depois do fechamento da votação, anunciaram o triunfo do J usticialismo -, e mostrando claras vitórias do Partido nas eleições de governador, senador provincial, deputados provinciais e vereadores. Em compensação, os números revelavam uma vantagem estreita e decrescente do candidato a prefeito, Simoni, sobre seu adversário radical. Se, por um lado, o clima na sede partidária continuava sendo de excitação, por outro, a versão da traição começava a adquirir força: o Doutor e os seus, dizia-se, não só teriam mandado cortar a cédula, como também haviam feito com que sua gente votasse no candidato da UCR.

Os primeiros a serem surpreendidos pelos resultados foram os radicais - que só saíram para festejar diante da Prefeitura, na praça principal da cidade, às 23 horas - e os meios de comunicação - que foram obrigados a destacar, com urgência, pessoal para a sede da UCR. Enquanto isso, como sabemos, na sede justicialista estourava a violência, transmitida diretamente para toda a cidade pelos dois canais de televisão.

De certa forma, pode-se dizer que essa violência se converteu na notícia mais relevante para os meios de comunicação locais, ofuscando o próprio fato da derrota peronista. Na manhã seguinte, o jornal dos radicais publicava no estilo característico de seu editorialista: 
“Imediatamente, o deputado Solari dirigiu-se aos presentes em um discurso improvisado que, aparentemente, analisava as causas da derrota na prefeitura, e pareceu, já que tudo isto era televisionado ao vivo pelo canal 6 , que se estava fazendo alusão a uma traição dentro do partido. Imediatamente, formou-se um grupo entre al guns dos presentes que tentou arrancar o microfone de Solari; e, no tumulto, se pôde ver que o Dr. Esteban Carbonari foi selvagemente espancado, ficando caído no chão".

O semanário local publicou, mais tarde, uma nota que refletia com fidelidade o estado de coisas imediatamente posterior à derrota:

“Eram apenas seis horas da tarde e o que havia eram apenas resultados de pesquisas de boca-de-urna, quando um grupo de simpatizantes justicialistas já expressava seu descontentamento e acusava certo setor interno de traidor. As acusações mais severas recaíram sobre Esteban Carbonari, Ramón Córdoba e a futura vereadora Nilda Avente [...].

Desde o fim de semana estava claro que alguns trabalhavam abertamente para o [candidato a prefeito] radical Liporacce. A senhora [...] [presidenta] do Sindicato das Donas de Casa, filiada e dirigente justicialista, manifestou publicamente sua adesão a Liporacce e pediu votos para o Radicalismo. Também o ex-senador Tato Ortega distribuiu envelopes com cédulas cortadas, e afirma-se que ele incluiu a UCR nas candidaturas locais. Isto teria chegado aos ouvidos de Solari, que os subestimou em quantidade e peso e, na hora da derrota, alguns pares o recriminaram por sua falta de ação para deter a conspiração. O filiado Pablo Rafael Dieguez também denunciou as ameaças na segunda-feira. Tampouco se salvou o senador Nardone, acusado de ter aconselhado o voto a favor da oposição radical [...]. De qualquer forma, ninguém acredita que entre os furiosos exista alguém capaz de degolar cabeças, mas assim mesmo ninguém duvida que, nos próximos meses, vão querer ver algumas delas rolando, politicamente falando, é claro [...].

\section{Dos fatos à traição}

Embora o relato precedente aspire reconstituir os acontecimentos narrados, combinando várias fontes de informação para elaborar uma versão que só pode ser a nossa, a dos antropólogos, o leitor deve ter percebido que durante a descrição dos acontecimentos posteriores à prévia justicialista adotamos o ponto de vista dos militantes do grupo de Solari Solari. Deliberadamente, falamos de “indícios" de que algo fora do comum iria 
acontecer, e de sua transformação em "presságios" de traição. De fato, no período comentado reinava entre esses militantes um sentimento de inquietação, um crescente temor de que o Doutor e os seus entregassem seus votos aos radicais. A versão da traição, que começara antes das eleições na forma de uma série de eventos que foram interpretados como presságios da desgraça por vir, se impôs de maneira imediata no fim da votação. Quando Solari mencionou os traidores em seu discurso, as pessoas sabiam exatamente de quem se estava falando porque há muito se suspeitava deles. Dias mais tarde, o reconhecimento público da presidenta do Sindicato das Donas de Casa, admitindo ter votado no candidato radical, não fez mais do que confirmar a suspeita.

O tempo também não conseguiu modificar a impressão dominante de que a derrota do candidato a prefeito foi produto de uma traição. Enquanto escrevíamos uma primeira versão deste trabalho, a três dias do primeiro aniversário do fato, escutamos na rádio FM local o locutor do programa de maior audiência chamar de "companheiros boinas brancas" aos peronistas que tinham votado a favor do radicalismo na eleição para prefeito. A brincadeira - que combinava o apelativo companheiros, utilizado entre peronistas, com a menção das boinas brancas, que tradicionalmente identificam os radicais - mereceu como resposta apenas uma carta, na qual as pessoas a quem o jornalista fazia referência adotavam de bom grado o apelido, unindo-se ao tom alegre de seu interlocutor. Significativamente, no entanto, nem a carta, nem o jornalista mencionaram nome algum: ainda hoje quem votou nos radicais prefere em geral ocultar sua identidade.

Cabe perguntar-se, por outro lado, até que ponto é certa a versão de que houve uma traição. Porque, na verdade, existe uma clara distância entre os fatos que podem ser comprovados e as implicações da versão da traição. A nota do semanário que reproduzimos ilustra este ponto quando diz: "Também o ex-senador Tato Ortega distribuiu envelopes com cédulas cortadas, e afirma-se que ele incluiu a UCR nas candidaturas locais". A diferença entre aquilo que podemos afirmar com certeza e o que supõe a versão da traição é aquela que existe entre o "distribuiu", referido às cédulas peronistas cortadas, e o "afirma-se que ele incluiu", referido às cédulas radicais para candidaturas locais. Ninguém pode demonstrar que M oncho Córdoba, Nilda Avente, Pablo Dieguez e os demais militantes do grupo do Doutor distribuíram as cédulas peronistas cortadas, incluindo o fragmento da cédula radical correspondente à candidatura a prefeito.

São várias as razões pelas quais é impossível provar a traição. Por um lado, a própria organização do processo eleitoral o impede. A cidade 
estava dividida em duas zonas eleitorais, com dois lugares de votação em cada uma, onde a população era distribuída alfabeticamente em mesas masculinas e femininas. Esta organização torna impossível uma avaliação em bases confiáveis do comportamento do eleitorado de cada bairro da cidade. Isto significa que não se pode saber, por exemplo, se os eventuais votos que consistiam em cédulas peronistas cortadas combinadas com o fragmento da cédula radical dedicado à Prefeitura correspondem ou não aos votantes levados por Pablo Dieguez ou por M oncho, porque tais votos aparecem misturados nas mesmas urnas com os de votantes de outros bairros controlados por outros cabos eleitorais. Qualquer um pode ter cortado as cédulas dessa maneira, incluindo os votantes levados pelos militantes do grupo do candidato derrotado, sendo, portanto, impossível determiná-lo a posteriori.

Se, por um lado, foram achadas cédulas cortadas nos veículos utilizados pela gente do Doutor, por outro, não foram encontradas cédulas radicais para prefeito. Finalmente, não houve, antes das eleições, declarações públicas - nem privadas de que se tenha notícia - do Doutor, ou de seus principais colaboradores, conclamando seus seguidores a votar na UCR. Só se expressaram, nesse sentido, militantes de pouco peso - dentre os quais Pablo Dieguez, um simples cabo eleitoral de bairro, é o que mais se destaca - , o que não prova em absoluto que o Doutor e os seus tenham optado organicamente por favorecer o candidato radical. De fato, a negociação que culminou com a inclusão de Nilda Avente na lista de vereadores parece indicar que o Doutor não tinha intenção de promover o voto nos radicais. Quanto a M oncho Córdoba, nem sequer há provas que o incriminem individualmente: eleitores levados por ele comentaram conosco que ele Ihes havia entregue cédulas cortadas, mas em nenhum momento mencionaram a inclusão do candidato radical à Prefeitura.

Em suma, é claro que não podemos saber se a entrega de votos existiu ou não e, no caso de ter existido, se foi uma decisão orgânica do grupo ou se as indecisões do Doutor no período posterior às prévias fizeram com que cada um de seus militantes de terceira, quarta linhas se sentisse livre para tomar suas próprias decisões no momento da votação. Não é isso, no entanto, o que nos interessa determinar. O que sim é relevante é que os dirigentes, militantes e votantes da facção de J ulio Solari pensaram que essa entrega de votos existiu e que foi uma decisão unificada do grupo opositor. Importa, também, o fato de que a consideraram uma traição e que, dentre todos os supostos traidores, destacaram como culpado - além do condutor do grupo - M oncho Córdoba, a despeito de ele não ter tornado pública sua suposta intenção de promover o voto no candida- 
to radical, ao contrário de outros cabos el eitorais da facção. Assim, nos dedicaremos a examinar a interpretação dada aos fatos pelos atores, mais do que os fatos em si mesmos.

O problema em questão revela-se mais complexo quando se olha para dois fatos fundamentais. Em primeiro lugar, não se trata de uma, mas de duas traições: uma coletiva, do Doutor e de sua gente ao Partido, e outra individual, de M oncho a Solari. Em segundo, embora todos os militantes da facção acusada da entrega de votos tenham sido considerados traidores, superada a exaltação inicial, a responsabilidade por essa entrega e por seus efeitos passou a ser atribuída, principalmente, ao Doutor e a M oncho. M ais adiante examinaremos a complexa relação entre as duas traições, que nos parece ser a chave da compreensão do próprio sentido do uso do termo traição nesse contexto. No momento, nos ocuparemos da progressiva concentração da responsabilidade sobre os nossos dois protagonistas.

A explicação dessa concentração é diferente em cada caso. Ao Doutor cabe uma responsabilidade central porque é ele quem encabeça o grupo, e se supõe que a entrega de votos correspondeu a uma decisão que, em última instância, foi sua. Como vimos, ninguém pode provar tal coisa, mas trata-se de uma crença legitimada pela maneira como usualmente operam os setores internos do Partido no plano local (como veremos adiante com relação à facção de Solari). Por outro lado, mesmo que não tivesse sido uma decisão orgânica da facção, isto é, uma ordem do Doutor, ele tem como obrigação controlar seus cabos eleitorais e militantes.

Quanto a M oncho, ele não só é acusado de duas traições, como também é considerado responsável pela derrota. Solari e os seus afirmam que ele controlava aproximadamente setenta votos e, dado que a derrota do Partido foi por uma diferença de 91 votos, inferem que a transferência desses eleitores do seu setor para o do Doutor foi uma das razões - se não a razão - da derrota. Dessa forma, a primeira traição, a de M oncho a Solari, só aparece a partir dos efeitos da segunda traição, a do Doutor e sua gente ao Partido. A responsabilidade individual de $\mathrm{M}$ oncho se expande até ocupar - junto com a do Doutor e talvez acima da dele - o lugar da responsabilidade coletiva de todos os companheiros acusados de entregar seus votos aos radicais. 


\section{Traição e confiança}

Temos, desse modo, duas situações diferentes - ainda que inter-relacionadas - qualificadas pelos atores de uma só maneira. O ponto a ser analisado, portanto, diz respeito às bases ou fundamentos dos laços que foram rompidos em cada caso. Devemos, assim, analisar as formas de confiança implicadas a fim de determinar exatamente o sentido que reveste o termo "traição" quando é aplicado a cada evento em particular. Georg Simmel (1939:340) define a confiança como "uma hipótese sobre a conduta futura de outrem, hipótese que oferece segurança suficiente para fundar nela uma atividade prática." E acrescenta que, sendo uma hipótese, ela constitui um grau intermediário entre o saber acerca dos outros e a ignorância a respeito deles. Isto o leva a se perguntar em que grau saber e ignorância se confundem para tornar possível a decisão prática, fundada na confiança. O autor responde, afirmando que "a época, a esfera de interesses, os indivíduos são os fatores decisivos" (Simmel 1939:340). O que significa que estamos diante de um fenômeno socialmente situado e que para explicar os limites e a forma da confiança devemos analisar, para cada caso particular, a maneira pela qual os atores a conceituam e constroem.

Em um conhecido texto programático, Ward Goodenough afirmava que: "A presentar-se como membro de uma comunidade ou de qual quer outro grupo social é comprometer-se a respeitar suas regras. Não respeitá-las é trair uma confiança" (1975:213).

No entanto, recorrer ao conceito de confiança para se referir à constituição de grupos não é muito comum na literatura antropológica. Em geral, o termo "confiança" tem sido usado para fazer referência ao conhecimento mútuo presente na base das relações diádicas em geral (cf. Blau 1964) e, de forma típica, do clientelismo (cf. Eisenstadt e Roniger 1984). Geralmente, esse tipo de confiança é considerado como produto e, ao mesmo tempo, fundamento de séries de intercâmbios recíprocos. No entanto, ao ir além das relações diádicas para analisar os fundamentos de relações complexas de pertencimento a grupos, os antropólogos não falaram de "confiança" em um sentido claro ou mesmo unívoco. O próprio Goodenough, que a relaciona com sentimentos associados à moralidade, não oferece um desenvolvimento exaustivo do conceito.

Em termos gerais, os antropólogos trataram o cimento das relações intragrupais em termos de "identidade", "solidariedade", "exclusividade moral", "limites" que são "mantidos" e outros conceitos. Nessas bases, analisou-se uma extensa gama de fatos sociais, tais como rituais, cerimo- 
niais, jogos, fofocas, estilos de vestimenta e muitos outros em que se destaca, mais uma vez, a reciprocidade. Da perspectiva de Simmel, no entanto, podemos dizer que atividades e padrões simbólicos, como os mencionados, permitem a criação de formas específicas de confiança que caracterizam cada tipo de agrupamento social e, mais particularmente, cada agrupamento concreto.

No nosso caso, encontramo-nos diante de: (a) relações entre membros de um partido político e (b) relações entre os militantes e o líder de uma facção do mesmo partido. Para analisá-las será útil a distinção realizada por Simmel (1939:340-341) entre dois tipos de confiança: aquela baseada no conhecimento pessoal do outro, isto é, no conhecimento de suas "qualidades pessoais"; e aquela que se baseia no conhecimento de certas exterioridades referentes ao outro, ou seja, um conhecimento geral "que só se refere à objetividade da pessoa", aos signos visíveis de sua condição social. Simmel tendia a considerar estes tipos como momentos históricos diferentes: a paulatina "objetivação da cultura" teria conduzido a confiança fundada em exterioridades a substituir em grande medida aquela baseada no conhecimento pessoal, predominante em "circunstâncias mais primitivas e menos diferenciadas". Hoje, as "tradições e instituições, o poder da opinião pública e o rigor da situação de cada um" determinam tão inexoravelmente a conduta do indivíduo que basta conhecer certas exterioridades para gerar a confiança. Independente do valor desta hipótese evolutiva, o próprio Simmel afirma que a confiança baseada no conhecimento pessoal continua sendo estratégica nos casos em que a associação entre dois indivíduos "tem uma importância essencial para a existência total destes", como, por exemplo, nas relações entre sócios comerciais (Simmel 1939:341). Na verdade, parece sensato supor que, em muitos casos, a confiança presente na base de uma relação social apresenta uma combinação de conhecimento de traços externos e de conhecimento pessoal.

No que diz respeito ao nosso caso, na medida em que lidamos com dois tipos de relações e, em conseqüência, com duas formas de confiança, verificamos que a incidência relativa dos dois tipos de conhecimento não é a mesma. Não obstante, como veremos a seguir, as duas formas de confiança compartilham certos traços críticos para a compreensão do sentido estrito da acusação de "traição" levantada contra M oncho e o Doutor. 


\section{Lealdade e traição}

$\mathrm{Na}$ análise da ruptura da relação partidária, na presumida entrega de votos ao adversário radical, deparamo-nos com a violação de uma forma de confiança fortemente objetivada. Se é certo que os membros de um partido político estão vinculados entre si por uma complexa rede de relações pessoais, e é igualmente certo que em um universo pequeno como o da cidade em questão todos esses militantes se conhecem pessoalmente, o pertencimento ao partido encontra-se sustentado genericamente por uma forma de confiança que remete a traços externos, visíveis, muito mais do que àquele conhecimento pessoal. A confiança básica existente entre os membros de um partido político resulta, substancialmente, da adesão a símbolos comuns: no caso do J usticialismo, a confiança entre companheiros é construída em termos do conceito de lealdade.

A história do conceito peronista de lealdade remonta ao dia 17 de outubro de 1945. Não tentaremos resenhar os acontecimentos desse dia - a imensa mobilização popular apoiando o então coronel J uan Domingo Perón, detido pelo governo militar que ele mesmo integrava -, que foram objeto de vários estudos (cf. os compilados por Torre 1995). O que nos interessa é assinalar que os dois primeiros governos de Perón presenciaram a construção de um discurso em que o 17 de outubro aparece como o dia da lealdade. Segundo Federico Neiburg (1995), o discurso acerca dessa data constitui o mito de origem do peronismo. Sua elaboração parece se relacionar com as características de sua base política uma aliança de partidos heterogêneos que começou a se quebrar imediatamente após as eleições que levaram Perón ao governo (Plotkin 1995:174 e ss.) - e social - a nova classe operária da cidade de Buenos Aires, de origem rural, um ator novo na política argentina. Esse discurso teria sido um instrumento no sentido da conformação do M ovimento peronista, centrado no líder, heterogêneo e apenas parcialmente institucionalizado na forma de partido político. Essa função política se revela na considerável distância existente entre seu conteúdo e os fatos históricos (apontada por diversos autores, como Navarro 1995; Plotkin 1995; N eiburg 1995), assim como nas reformulações de que foi objeto antes e depois do gol pe de Estado que derrubou Perón em 1955.

Esse discurso está centrado nas relações entre três atores. Por um lado, a relação entre o líder e seus seguidores, os descamisados, que demonstraram sua lealdade a Perón, exigindo sua libertação. A mobilização do povo na jornada do 17 de outubro encarna as principais características associadas ao conceito de leal dade: a fidelidade — representada 
pela esposa do líder, Eva Perón, Evita, fiel a Perón em seu momento mais obscuro (Navarro 1995:155, 166) - e a militância - os descamisados, mobilizando-se por ele. Por outro lado, o discurso contrapõe essa relação àquela existente entre Perón e seus antigos amigos do governo militar que o haviam encarcerado, os traidores, nunca claramente identificados (Plotkin 1995:197). Assim, leais e traidores opõem-se, em virtude de suas atitudes contrárias para com o líder.

Para além das transformações históricas desse discurso, o certo é que o par de conceitos opostos se manteve como um componente essencial do simbolismo peronista. A ceite-se ou não considerá-lo como um mito de origem, o fato é que o discurso acerca do 17 de outubro fez pelo peronismo aquilo que, segundo N eiburg (1995:231), fazem esses mitos: falando do passado, proporcionam categorias que permitem "compreender o presente e planejar o futuro". Efetivamente, fatos e figuras da história política da Argentina dos últimos cinqüenta anos continuaram sendo apresentados por discursos emanados do peronismo em termos de lealdade e traição. E, na medida em que estas categorias estruturam a percepção da realidade, operam também como fatores centrais de estruturação das condutas: a do militante peronista e a do companheiro - o simpatizante peronista em geral, milite ou não. Poder-se-ia dizer, nesse sentido, que o conceito de leal dade opera como uma espécie de princípio articulador (Cohen 1974:102) do movimento peronista9: como uma forma simbólica que, em virtude de determinados processos históricos e do potencial simbólico que sua flexibilidade Ihe confere, adquiriu um caráter predominante em sua organização.

A confiança existe entre peronistas na medida em que a lealdade pode ser tida como certa: confia-se em um companheiro porque se supõe que ele ou ela é leal, ou seja, é fiel (a Perón, ao líder, ao movimento, ao partido) e que milita em favor da causa comum. Ser confiável é, pois, ser leal, e isto supõe certamente demonstrá-lo quando a ocasião o requer. Contudo, mais freqüentemente, supõe exprimir a lealdade mais do que demonstrá-la. Esta expressão é produzida através da adesão manifesta e cotidiana aos símbolos da lealdade: uma linguagem (companheiros, lealdade, dia da lealdade, Evita etc.), palavras de ordem (Perón voltará; a vida por Perón; para um peronista não há nada melhor do que outro peronista etc.), a marcha peronista etc. Esse leque de recursos simbólicos é responsável por produzir e reproduzir cotidianamente a confiança básica que cimenta as relações entre os militantes peronistas. No entanto, essas formas simbólicas não são suficientes para manter a confiança quando se quebram as solidariedades que nela se fundam. 
A o romper-se a solidariedade que a confiança sustenta e supõe, esta se esvai rapidamente. Ora, é de se esperar que isto seja conceituado pelos atores em termos dos símbolos que objetivam a confiança - neste caso, em termos do par de opostos conformado pelos conceitos de lealdade e traição. É o que ocorre na situação que nos ocupa; não se trata, porém, de um efeito automático da presença do conceito de lealdade como princípio articulador do movimento. De fato, como qualquer balanço superficial da história do peronismo seria capaz de mostrar, nem todas as ações que, em abstrato, constituiriam traições em termos desses símbolos são representadas dessa forma pelos atores, nem estes assumem uma atitude unificada perante cada uma delas. Falar de traição e de traidores é atribuir ex-post facto determinados significados a eventos e pessoas, e tal atribuição nunca é uma função automática do conteúdo dos conceitos definidos abstratamente, mas o produto de um processo concreto de interpretação socialmente delimitado. É preciso, pois, ater-se a cada situação social em toda a sua complexidade.

A creditamos que para explicar completamente a aplicação do conceito de traição ao nosso caso, é necessário considerar os efeitos das ações em questão e o caráter específico das relações existentes entre os atores no momento dos acontecimentos - fatores que qualificam a situação para além do fato de que foi registrada uma ruptura da solidariedade fundada na confiança genérica existente entre companheiros. Em primeiro lugar, o efeito desastroso atribuído à suposta entrega de votos (a perda da Prefeitura) contrastou fortemente com o amplo triunfo conseguido pelo Partido na votação para a composição da Câmara de Vereadores. A notável diferença existente entre a derrota por 91 votos em um caso e a vitória por 608 votos no outro só podia conduzir à atribuição ao grupo dissidente de uma responsabilidade excludente pela derrota. Ao encontrarem cédulas nas quais faltava precisamente a parte do voto para prefeito nos veículos empregados pelos homens do Doutor, era natural concluir que sem esse corte o Partido teria conservado a Prefeitura. Em segundo lugar, não só o Doutor e os seus eram confiáveis a priori por serem companheiros, como até o último momento tinham negociado sua incorporação ao novo governo, e o nome de Nilda Avente tinha sido incluído na lista de candidatos a vereadores. N essas condições, a entrega de votos ao adversário não aparecia somente como sub-reptícia, mas como mal-intencionada, porque a relação entre as duas facções era, formalmente, uma aliança, ainda que tensa. A té o último momento, o Doutor havia manifestado sua lealdade e, apesar das declarações ameaçadoras de alguns militantes de seu grupo, sua vontade negociadora parecia sugerir que os acontecimen- 
tos não se desviariam do curso normal. N esse sentido, na medida em que o Doutor negociara e estabelecera uma aliança com o vencedor, pode-se dizer que a confiança quebrada não se fundava somente no conhecimento de exterioridades referentes aos vencidos (o conhecimento dos "signos visíveis" de sua lealdade), mas também em um conhecimento pessoal (o do compromisso assumido pelo Doutor, implícito no acordo). Daí, cremos, o caráter extremo da reação dos envolvidos, daí a acusação de traição.

Como dissemos, a relação entre J ulio Solari e M oncho Córdoba era tanto política quanto pessoal: M oncho era homem da confiança de Solari, não um simples militante, e essa confiança se fundava em uma relação pessoal duradoura construída ao longo da atividade política compartilhada. Estamos, pois, diante da ruptura de uma relação política pessoal. De fato, no plano político local, as relações entre líderes e seguidores geralmente pertencem a esta categoria: entre eles existe confiança porque existe um conhecimento pessoal desenvolvido através de prolongados intercâmbios recíprocos. Não obstante, essas relações são também relações entre companheiros e, em conseqüência, ficam presas aos parâmetros do princípio articulador que predomina na organização do movimento: são construídas e expressas em termos do conceito de lealdade.

Com efeito, os seguidores de Solari manifestavam sua lealdade cotidianamente através de uma série de expressões que ressaltam o caráter indissolúvel da relação. M oncho costumava dizer que Solari era "como um pai" para ele, expressão que outros de seus seguidores também empregavam. A disposição de arriscar a vida e de matar pelo líder aparece como manifestação de lealdade. Em uma ocasião, quando a relação de M oncho com Solari vivia o seu melhor momento, o primeiro ostentava a sua exaltação toda vez que tinha que enfrentar os rivais de seu chefe na luta pelo controle do peronismo local. Referindo-se à sua reação diante de uma manifestação sindical contra Solari (então prefeito), que ele supunha arquitetada pelos adversários internos, M oncho nos dizia:

“Ontem à noite no bingo [depois da manifestação], quando Solari estava indo embora, ele me disse para que eu me acalmasse, para que eu tentasse ajeitar as coisas, porque eu, com whisky além da conta, queria ir pra cima deles. Eu disse a Solari: 'olha irmão, eu sou leal; se é preciso dar comida aos 'corvos' [os adversários internos], eu dou. Por você, irmão, porque é você quem está me pedindo. Agora, se um dia eu matar um 'corvo', não venha me dizer nada'". 
No discurso desses homens, a lealdade aparece como um parâmetro imutável de suas vidas. Assim, suas manifestações se fazem particularmente explícitas nos momentos em que suas relações são submetidas a grandes tensões que ameaçam rompê-las. Quando a relação já estava deteriorada, M oncho afirmava que devia tudo a Solari e que, por isso, se mantinha junto dele, ainda que suas ações o prejudicassem. Em 1996, em um jantar com antropólogos, um militante muito próximo a Solari o culpava porque a derrota havia implicado a perda de seu cargo na Prefeitura. No entanto, fazia questão de manifestar sua lealdade ao líder, de quem dizia gostar como a um pai e prometia acompanhá-lo sempre, a despeito de tudo.

A pesar de suas naturezas distintas, a confiança fundadora da solidariedade partidária e a confiança como base da relação entre o líder e seus seguidores são construídas e mantidas através dos mesmos símbolos. Isto é função, como já foi dito, do fato de que aqueles que se encontram vinculados como líder e seguidor são, em um plano mais geral ou mais básico de sua relação, companheiros: a relação entre membros do movimento e do partido subsume a relação hierárquica personalizada que se estabelece entre alguns deles. Outro fator que contribui para explicar essa identidade simbólica é a inexistência prática do Partido J usticialista enquanto organização formal na esfera local: os organismos partidários têm uma existência meramente formal, e as divisões internas do partido geralmente não estão constituídas formalmente como grupos ou linhas internas. Assim, o grupo liderado por Solari é um grupo informal, completamente centrado na sua pessoa e estruturado por sua liderança. N essas condições, como chama a atenção Cohen (1974), os símbolos capazes de operar como princípios articuladores adquirem particular importância e, dado o fato de que se trata de um grupo peronista, o conceito de lealdade aparece com maiores possibilidades de ocupar essa posição.

Tudo o que foi dito até aqui contribui para esclarecer o sentido da acusação de traição que recaiu sobre M oncho, mas não é suficiente para explicá-la. Mais uma vez, encontramo-nos diante de uma atribuição de sentido que não pode ser explicada em função de conceitos abstratos. $M$ as isso não é tudo, pois o rompimento de M oncho com Solari e sua peregrinação interna em direção aos seguidores do Doutor não foram imediatamente considerados como uma traição: somente quando se soube o resultado das eleições, quando se conheceu a derrota, é que o nosso homem foi qualificado como traidor.

De fato, no período em que estiveram separados até as eleições, nenhuma voz se levantou para acusar M oncho de ter feito algo reprová- 
vel. Sua migração até o setor do Doutor fora pública, e ocorrera como efeito de uma série de reveses políticos sofridos em poucos meses. Nessas condições, parecia lógico que M oncho buscasse novos ares, uma atitude muito comum na política e considerada perfeitamente natural. Nem todo aquele que muda de grupo é um traidor: sê-lo ou não, depende das circunstâncias e efeitos de sua ação. Para desgraça de M oncho, no entanto, as circunstâncias não são dados objetivos, e os efeitos atribuídos às suas ações modificaram completamente a maneira pela qual seus companheiros as encaravam. $O$ que é natural enquanto se organiza o baile da vitória passa a ser uma aberração quando se vê na televisão a comemoração dos adversários.

O ponto é que, estritamente falando, a segunda traição foi a primeira. Quando os perdedores consideraram que M oncho tinha entregue seus votos aos radicais - os votos causadores da derrota -, sentiram retrospectivamente que este já os havia traído ao passar para o lado do Doutor. Se antes parecia que Solari virtual mente o havia empurrado para procurar um novo chefe político, depois pareceu que M oncho tinha saído por vontade própria - uma pirueta política rotineira passou a ser entendida como o rompimento da confiança pessoal que o líder havia depositado em seu cabo el eitoral. A crença de que havia ocorrido uma traição no dia das eleições produziu uma ressignificação das ações passadas de M oncho, convertendo-as, aos olhos dos perdedores, em uma traição anterior e, em certo sentido, mais perversa. O processo de atribuição de sentidos - a criação das traições - seguiu uma ordem inversa à do desenvolvimento dos acontecimentos: M oncho separou-se de Solari e se uniu ao Doutor antes das eleições, mas a traição que se supõe ter sido cometida em seu decorrer foi, de fato, anterior àquela que atingiu seu antigo líder.

\section{O preço da traição}

Qual é, então, o significado da acusação de traição que se fazia aos nossos homens? A traição é entendida aqui como a atitude oposta à lealdade peronista. J á vimos que a fidelidade e a militância são suas características principais. Nesse sentido, quando o Doutor e M oncho são chamados de traidores, estão sendo acusados de serem infiéis e de terem falhado como militantes. Mas, o que significa isto? Quando se trata de um companheiro que não se dedica ativamente à política, espera-se dele que participe dos atos partidários, que utilize certa linguagem e pronuncie certas palavras de ordem, e sobretudo que vote nos candidatos do partido. Porém, quan- 
do se trata de um militante, espera-se algo mais, que trabalhe para o partido nas tarefas que lhe são atribuídas e, particularmente, que consiga votos. Os votos são o capital do partido, o capital de cada um de seus grupos internos, e também o de um militante. E é aqui, precisamente, que se localiza a falta atribuída aos nossos homens. Quando o Doutor e sua gente entregaram seus votos aos radicais, despojaram o Partido de seu bem mais precioso; e quando M oncho se uniu ao Doutor, não só despojou Solari de uma parte de tais bens, como preparou a perda que o Partido sofreu logo em seguida, conferindo-Ihe seu caráter efetivo. Assim, eles faltaram, ou pelo menos nisso acreditam seus companheiros, com sua obrigação fundamental como militantes peronistas: foram infiéis, e o foram, precisamente, com respeito à obrigação capital de um militante.

Inevitavelmente, os protagonistas de nossa história tiveram que pagar o preço de sua traição. Como é de se esperar, a falta atingiu de diferentes maneiras cada um deles. Por um lado, o Doutor sofreu apenas a perda da confiança do restante do Partido, o que significou para ele um certo retrocesso político, mas seguiu à frente de seu grupo, convertido em um dos dois referenciais mais importantes do peronismo local. Por outro, M oncho viu-se excluído da política local: não voltou a ocupar cargos públicos nem partidários, nem sequer atua mais como cabo eleitoral.

Estas diferenças são, em grande medida, uma imposição do pragmatismo político. O Doutor lidera uma facção de grande peso, e isto teve de ser reconhecido, quando, uma vez passado o furor inicial, seus adversários tiveram a oportunidade de parar e pensar que linchá-lo talvez não fosse uma idéia tão boa. Ninguém no peronismo quer, obviamente, que o Doutor vá para a Frepaso, o que favoreceria não só esse partido, mas, indiretamente, o grande adversário local, o Radicalismo. Quanto a M oncho, ao perder a confiança dos companheiros, tornou-se inviável sua permanência dentro do Partido, ficando o Doutor impossibilitado de negociar qualquer posição para ele. Tampouco pode ser cabo eleitoral, porque perdeu toda a capacidade de obter recursos de seus companheiros para manter sob controle um grupo de el eitores. Curiosamente, o único traço em comum das reações partidárias contra nossos homens é o melhor indicador das dramáticas diferenças que existem entre seus casos: o Doutor não recebeu nenhuma sanção formal do Partido porque isso poderia tê-lo empurrado para a Frepaso, enquanto $M$ oncho não foi punido porque sua morte política já era um fato consumado.

Por outro lado, o destino de M oncho também é função da gravidade particular de sua falta. Enquanto o futuro dos demais cabos el eitorais e militantes do grupo do Doutor está intimamente associado ao seu - por- 
que o peso de sua figura absorve de certo modo a responsabilidade de seus seguidores -, a dupla traição de M oncho o exclui dessa proteção. Para ele, seus antigos amigos têm apenas uma frase cruel que, freqüentemente, se aplica a quem é condenado ao desterro político: [...] Frasquito de anchoas, diez mil kilómetros de desierto, [...] y después conversamos. ${ }^{*}$

\section{À guisa de conclusão: senso comum, sentidos "nativos" e categorias científicas}

O que fizemos nestas páginas foi exercitar o sadio costume antropológico de nos perguntarmos acerca do óbvio. Por que traição? Por que os militantes e dirigentes do grupo de J ulio Solari se sentiram traídos? Ou, de maneira mais geral, o que queriam dizer quando gritavam traição?

Trata-se de perguntas poucas vezes colocadas pelos antropólogos, que mencionam ocasionalmente "traições" e "traidores", mas raramente analisam o sentido desses termos. Bailey, por exemplo, em um livro tão adequado para isso quanto Stratagems and Spoils (Bailey 1980), não se detém a analisar o sentido do termo "traidor" na única ocasião em que o emprega. Devemos atribuir este fato, talvez, a uma naturalização do conceito. Na nossa cultura, o conceito de traição refere-se à ruptura de lealdades ou fidelidades e, especialmente, a seu rompimento sub-reptício, que deixa os atingidos sem defesa. Sendo óbvio que essas coisas ocorrem em todas as culturas, os antropólogos parecem supor que todas possuem um conceito análogo ao nosso para descrevê-las: quando encontramos as palavras traição e traidor, seu sentido nunca é explicitado, pressupondo que o leitor as compreende; e, o mais importante, não se explica se os eventos e pessoas descritos são chamados assim por iniciativa do antropólogo ou porque os atores os qualificam com expressões análogas às que ele emprega.

Consideremos, por exemplo, o artigo de Maurice Godelier (1989) sobre as traições entre os Baruya da Nova Guiné, que constituiu a fonte de inspiração inicial para o nosso próprio trabalho. Trata-se de uma bri-

\footnotetext{
* N.T. - Através de referências implícitas ao desterro e à morte, esta frase sugere que a carreira política de seu destinatário chegou ao fim. Seu sentido fica evidente quando se explicitam os subentendidos: [Pegue uma] Lata de anchovas, [caminhe] dez mil quilômetros de deserto, ...e [se conseguir sair com vida] depois conversamos. A imagem do longo caminho pelo deserto sugere o "desterro", um longo afastamento da atividade política. Entretanto, a menção de um alimento salgado e a cruel ironia final evocam imediatamente a idéia da morte. Na Argentina, é comum chamar de "mortos" os políticos que caíram em desgraça.
} 
Ihante análise de certos eventos que o autor agrupa em duas categorias claramente diferenciadas, às quais denomina globalmente de "traições". No texto, fica claramente estabelecido - ainda que apenas de maneira implícita - que todos os eventos em questão são considerados pelos atores como fenômenos do mesmo tipo, mas em nenhum momento se tenta explicar o sentido que é aplicado ao termo na língua nativa nem justificar seu tratamento em termos do nosso conceito de traição.

Em suma, os antropólogos tratam o conceito de traição como uma categoria sociológica, ou melhor, como uma categoria do nosso senso comum elevada ao nível de categoria sociológica. Isto, a princípio, é aceitável, mas o problema é que a qualificação de um evento como "traição" é sempre uma atribuição de sentido ex-post facto: alguém se sente traído e assim qualifica o fato que o afetou. Portanto, se podemos empregar um conceito sociológico de traição, é imprescindível analisar suas relações com o conceito usado em cada caso pelos atores para descrever cada evento específico abarcado por ele. Não fazê-lo supõe naturalizar nosso conceito, ter como certo que o conceito dos atores significa o mesmo que o nosso. Isto não pode ser sustentado nem sequer quando - como no caso aqui analisado - lidamos com atores da nossa própria cultura que, assim como nós, empregam os vocábulos "traição" e "traidor".

Não há nada de óbvio ou natural no sentido destes termos. Para nós, por exemplo, a traição é algo eminentemente negativo, como se pode comprovar em qualquer dicionário. No entanto, Godelier nos mostra que entre os Baruya, o rompimento sub-reptício de solidariedades - que os nativos denominam com um termo que ele traduz como "traição" - nem sempre é visto como algo reprovável. Pelo contrário, sua val oração depende do tipo de solidariedade afetada em cada caso, o que faz com que certas traições possam ser aceitáveis e mesmo el ogiáveis, o que basta para afirmar que a noção baruya não se encaixa em nosso conceito de "traição". Por outro lado, não se pode dizer que nós tratemos como "traições" a todos os atos que correspondam em abstrato ao nosso conceito. Como já tivemos oportunidade de dizer, a atribuição de significados a eventos, coisas e pessoas, nunca é uma função automática do conteúdo dos conceitos definidos abstratamente, mas é produto de um processo concreto de interpretação socialmente delimitado.

Por outro lado, se os fenômenos evocados por nossa definição abstrata de traição ocorrem aqui e ali, isso não justifica a suposição de que toda cultura deva tratá-Ios de modo unificado, através de um conceito análogo ao nosso. Assim, é perfeitamente possível especular sobre a existência de culturas que não disponham de um conceito que abarque - 
mesmo que só em abstrato - todas as quebras sub-reptícias de lealdades ou solidariedades.

Nessas condições, caberia talvez criar um novo conceito para abarcar esse tipo universal de fenômeno - caso se reconheça alguma utilidade analítica na opção de unificá-los a partir desse ponto de vista -, sem estender a todos os casos as conotações negativas do conceito de nosso próprio senso comum. Ou, como fizeram M arcel Mauss com o hau melanésio e tantos outros autores com o conceito de honra, talvez se possa generalizar com fins heurísticos o sentido do nosso conceito de "traição", construindo uma categoria geral transcultural. De todo modo, essas opções devem resultar de um extenso e detal hado trabal ho de análise comparativa transcultural, cujos materiais surgirão de estudos de casos como o que aqui tentamos realizar.

Tradução: Maria J osé A. Freire

Revisão técnica: Marcio Goldman e

Silvia Nogueira
Recebido em 12 de agosto de 1997

Reapresentado em 26 de janeiro de 1998

A provado em 9 de fevereiro de 1998

Mauricio Fernando Boivin é professor-associado do Departamento de Ciências A ntropológicas, Faculdade de Filosofia e Letras - Universidade de Buenos Aires. Ana Rosato é pesquisadora-assistente do Conselho Nacional de Pesquisas Científicas e Técnicas (Conicet) e professora-adjunta do curso de Ciências da Comunicação, Faculdade de Ciências Sociais - Universidade de Buenos Aires. Fernando Alberto Balbi é doutorando em Antropologia Social, PPGAS-MN-UFRJ e chefe de trabalhos práticos do Departamento de Ciências Antropológicas, Faculdade de Filosofia e Letras - Universidade de Buenos Aires. E-mail: mboivin@teletel.com.ar 


\section{Notas}

1 Denominam-se militantes os ativistas de um partido político. Os militantes desempenham todas as atividades proselitistas de um partido: distribuem panfletos, pintam e colam cartazes, organizam os atos partidários etc.

2 Nosso trabal ho na cidade remonta a 1986, quando iniciamos um projeto de pesquisa sobre "Estrutura Econômica e Políticas de Intervenção do Estado" na área (Conicet - UBA). Desde então, desenvolvemos ali uma série de pesquisas sobre diversos temas (produção pesqueira, programas de desenvolvimento rural, organização cooperativa, produção avícola etc.), detendo-nos, particularmente, nos seus vínculos com os processos políticos locais. Atualmente, estamos realizando uma pesquisa sobre o processo de integração regional em curso entre a província argentina de Entre Ríos e o estado brasileiro do Rio Grande do Sul. Este artigo constitui um dos primeiros produtos dessa pesquisa, cujo objetivo central é analisar as relações entre o processo de integração regional e os processos políticos locais de Entre Ríos. Devido à natureza dos acontecimentos aqui examinados, preservamos o nome da cidade onde eles aconteceram e as identidades neles envolvidas. Todos os nomes que utilizamos são imaginários, com exceção das figuras políticas nacionais.

3 A União Cívica Radical (UCR) - habitualmente conhecida como o “Radicalismo" - era, até as eleições de 1995, o principal partido de oposição nacional. Também era, e continua sendo, a maior força de oposição provincial. Raúl Ricardo Alfonsín, da UCR, presidiu a A rgentina entre 1983 e 1989, durante o primeiro período de governo democrático após a ditadura militar, que se estendeu de 1976 a 1983.

4 O Partido J usticialista (PJ ), usualmente chamado "Peronista" - por causa de seu fundador e líder histórico, J uan Domingo Perón - , detém o governo nacional desde 1989, quando Carlos Saul Menem derrotou Eduardo Angeloz, o candidato radical à sucessão do presidente Alfonsín. Em 1995, após uma controvertida reforma constitucional que o habilitou a se candidatar a um novo período de governo - pactuada, precisamente, com Alfonsín -, M enem obteve sua reeleição.

5 Um puntero é um militante que controla um certo número de votos presumidamente cativos. Através do proselitismo e prestando serviços para as pessoas de sua área de influência, estabelece seu controle sobre um conjunto de eleitores, colocando-os à disposição de seu partido e, dentro deste, do grupo de que faz parte. O nome puntero deriva da capacidade que se Ihes atribui de contar ("puntear") os votos de um determinado segmento da população.

6 Companheiro é o apelativo com o qual os peronistas se dirigem uns aos outros. Os radicais, por sua parte, utilizam o termo correligionário. 
7 A Frepaso é uma aliança que nas eleições nacionais de 1995 se situou como primeira força de oposição, suplantando a UCR. Trata-se de uma força que se autoqualifica como de centro-esquerda, e que é integrada por diversas dissidências do peronismo e por vários partidos socialistas, entre outras forças. O partido PAIS é então uma das duas principais forças da Frepaso, liderado por J osé Octavio “Pilo" Bordón, ex-governador da província de Mendoza pelo PJ . Nas eleições de 1995, Bordón foi candidato a presidente pela Frepaso, depois de derrotar de maneira surpreendente o também ex-justicialista Carlos “Chacho" Alvarez, outra referência importante da aliança, em eleições internas abertas — onde está habilitado a votar qualquer eleitor nacional, diferentemente das internas fechadas, onde votam somente os afiliados ao partido. A afinidade de um dos protagonistas da nossa história, o Doutor, com Bordón, está associada à origem peronista deste último.

8 N as eleições são utilizadas as chamadas cédulas "Iençóis": uma única cédula para cada chapa, contendo, em diferentes partes, as candidaturas para todos os cargos em disputa nos planos nacional, provincial e local. O eleitor pode cortar a cédula, isto é, remover as partes que deseja, a fim de votar em outros candidatos, ou abster-se em uma ou outra categoria. Não se permite, no entanto, rasurar ou emendar as cédulas.

9 A bner Cohen emprega o conceito de "princípio articulador" para analisar a organização dos grupos informais de interesse, tais como grupos étnicos, elites, grupos religiosos etc. (C ohen 1974:esp. caps. 5 e 6). Acreditamos que a presença destacada de princípios articuladores não é privativa dos grupos informais, uma vez que o peronismo é, em certa medida, um agrupamento informal. Por um lado, como foi dito, o peronismo caracterizou-se historicamente pelo fato de o partido que o expressa formalmente - o J usticialista - não representar cabalmente a complexa heterogeneidade do movimento; e, por outro, o partido tende a aparecer diluído tanto no discurso de seus membros - que se situam antes no movimento - quanto em suas práticas políticas - normal mente mais centradas em lideranças fortes que nos organismos partidários formais. 


\section{Referências bibliográficas}

BAILEY, F.G. 1980. Stratagems and Spoils. A Social Anthropology of Politics. Oxford: Basil Blackwell.

BLAU, Peter. 1964. Exchange and Power in Social Life. New York: J ohn Wiley and Sons.

COHEN, Abner. 1974. Two-dimensional Man. An Essay on the Anthropology of Power and Symbolism in Complex Society. London: Routledge \& Kegan Paul.

EISENSTADT, S.N. e RONIGER, L. 1984. Patrons, Clients and Friends. Interpersonal Relations and the Structure of Trust in Society. Cambridge: Cambridge University Press.

GODELIER, Maurice. 1989. “Betrayal: The Case of the New Guinea Baruya". Oceanía, 59(3).

GOODENOUGH, Ward. 1975. "Cultura, Lenguaje y Sociedad". In: J .S. Kahn (comp.), El Concepto de Cultura: Textos Fundamentales. Barcelona: Anagrama. pp. 157-249.

NAVARRO, Marysa. 1995. “Evita y la Crisis del 17 de Octubre de 1945; un Ejemplo de la Mitología Peronista y Antiperonista". In: J.C. Torre (comp.), El 17 de Octubre de 1945. Buenos Aires: Ariel. pp.149-170.

NEIBURG, Federico. 1995. “El 17 de Octubre de 1945: Un Análisis del M ito de Origen del Peronismo". In: J .C. Torre (comp.), El 17 de Octubre de 1945. Buenos Aires: Ariel. pp. 219-284.

PLOTKIN, Mariano. 1995. "Rituales Políticos, Imágenes y Carisma: La Celebración del 17 de Octubre y el Imaginario Peronista". In: J.C. Torre (comp.), El 17 de Octubre de 1945. Buenos Aires: Ariel. pp. 171-218.
SIM M EL, Georg. 1939. "EI Secreto y la Sociedad Secreta". In: Sociología. Estudios sobre las Formas de Socialización. Buenos Aires: EspasaCalpe. pp. 330-392.

TORRE, J . C. (comp.). 1995. El 17 de Octubre de 1945. Buenos Aires: Ariel. 


\section{Resumo}

No presente artigo, buscamos analisar alguns fatos ligados à derrota eleitoral sofrida pelo Partido J usticialista - no poder até então - em uma cidade da Mesopotâmia argentina, em 1995. Dirigentes e militantes do partido atribuíram a derrota para a prefeitura local a uma traição que teria sido cometida pelos membros de uma de suas facções, que teriam votado no candidato da oposição. Pretendemos examinar o significado dessa acusação e determinar as razões pelas quais a responsabilidade pela derrota foi atribuída, fundamentalmente, a dois homens. A análise do significado da acusação de traição concentrar-se-á nas formas de confiança que formam a base das relações sociais atingidas pelas rupturas qualificadas de traições. Isso nos leva à análise do conceito peronista de lealdade, que aparece como símbolo constitutivo fundamental da confiança que cimenta as relações entre os membros do partido. N ossa análise é etnográfica, ou seja, obtém seus materiais da observação participante e tem como eixo as variadas e mutáveis perspectivas dos atores - o que não significa considerá-las o elemento explicativo, mas situá-las em contextos teóricos que as tornem compreensíveis.
In this work, the authors propose an analysis of events surrounding the 1995 electoral defeat of the incumbent J usticialista Party in an Argentinean town. Party leaders and activists blamed the defeat on betrayal by members from another internal section of the party alleged to have voted for opposition candidates. The authors examine the meaning of this accusation and attempt to determine the reasons why responsibility for the defeat was attributed in essence to two men. Their analysis concentrates on the forms of confidence which form the basis of social relationships subsequently ruptured by allegations of betrayal. This leads into an analysis of the Peronist concept of loyalty, a concept which appears to constitute an underlying symbol of the confidence cementing the relationships between members of the party. The analysis is ethnographic, deriving its primary material from participant-observation, and takes as its axis the varied and mutable perspectives of the actors - not as self-explanatory elements, but as material rendered intelligible when placed in theoretical contexts. 